\title{
Calcagno, Antonio, The Philosophy of Edith Stein ${ }^{1}$
}

\section{Robert C. Cheeks}

\author{
One of the typical phenomena of the twentieth century is \\ the event of spiritually energetic people breaking out of the \\ dominant intellectual group in order to find the reality that \\ has been lost. - Eric Voeglin ${ }^{2}$
}

I $\mathrm{n}$ the introduction to her magnum opus, Finite and Eternal Being, Edith Stein writes, "For the self-limitation of his power as regards its external efficacy is itself act and effect of his power. God's potency is one, as his act is one, and in this one act his potency is completely actualized." Stein is referring to the Thomistic concept of act and potency, explicating that God's potency is expressed in his act, and while that act may not entail all that God could effect it is true that "there is nonetheless to God no surplus of potency vis-à-vis his act, no unactivated potency."”

Stein's comments provide a powerful pneumatic insight. A question, really, that simply asks, is our Free Will an expression of God's intentional selflimitation? Well, I should like to pursue that question, but my point here is that to read Edith Stein is to be stimulated by the possibilities of truth. She is a fascinating human being, a mystical philosopher seeking order in the "bond between Reason and existential phila."

A new book, The Philosophy of Edith Stein (Duquesne University Press, 2007 ) by Dr. Antonio Calcagno, assistant professor of philosophy at the University of Scranton, successfully plumes the rich materials of Stein's philosophical quest to a depth and detail that belies the meager 151 pages of the book.

"She is," Calcagno writes, "a relevant and contemporary thinker whose ideas and insights challenge us to think through the perennial problems that are proper to philosophy." ${ }^{4}$ Yes, she is that, and she is also one very complex human being.

The author provides in chapter one a look at these complexities: Stein the Jewish girl who embraced atheism as a teenager, converts to Catholicism at

\footnotetext{
1 Pittsburg: Duquesne University Press, 2007. 151 pp.

2 "Why Philosophize? To Recapture Reality," in Collected Works of Eric Voegelin, Vol. 12, Univ. of Missouri Press, 1990).

${ }^{3}$ Edith Stein, Finite and Eternal Being, The Collected Works of Edith Stein, Vol. Nine (Washington, D.C.: ICS Publications, Institute of Carmelite Studies, 2002), 2.

${ }^{4}$ Calcagno, op cit., $\mathrm{xv}$.
} 


\section{THE PHILOSOPHY OF EDITH STEIN}

thirty-one, and takes the veil at forty-six; the Catholic feminist, the victim of invidious sexism and racism, identified as Edmund Husserl's "secretary," accused of merely emulating Husserl's work, than victimized again by Heidegger who "took Stein's edited manuscript of Husserl's On the Phenomenology of the Consciousness of Internal Time and credited himself with editing it. ${ }^{5}$ In the face of all these insults and more, Stein never wavered.

It was Husserl's phenomenology that attracted Stein. "He claimed," Calcagno writes, "to have overcome the traditional distinction between appearance and the thing-in-itself, phenomenon and noumenon." That phenomenology was the "foundation for all knowledge in general and ... the study of consciousness and how consciousness comes to know the essential structures of things." 6

The author emphasizes the key point that Husserl's phenomenology demanded the examination "of the objective and essential nature of things in the world." The idea of faith, religion, and God long assigned to the philosophical back bench, are now reintroduced as legitimate and "lived experiences."

But as "thorough and competent" as Husserl's work was, it was not without its critics. Philosopher and political theorist Eric Voegelin commented that ". . . we also agreed on the insufficiencies of his analysis that had become all to obvious in the Meditations cartesiennes of 1931 and made it impossible to apply the phenomenological method, without further development, to the social phenomena that were our primary concern." 7

It was not until 1943 that Voegelin obtained a copy of Husserl's Krisis der europa ischen Wissenschaften. He was "shocked" by Husserl's "philosophy of history," where the last of the three phases in the history of man's reason, described by Husserl, began with "the 'apodictic beginning' set by his own work, and going on forever into the future, within the "horizon of apodictic continuation' of his phenomenology . . . I was horrified because I could not help recognizing the all too familiar type of phase constructions in which had indulged the Enlightenment philosophers and, after them, Comte, Hegel, and Marx. It was one more of the symbolisms created by apocalyptic-gnostic thinkers, with the purpose of abolishing a 'past history' of mankind and letting its 'true history' begin with the respective author's own work."

Were the roots of this Husserlian egophany found in his embrace of neo-Kantian "transcendental idealism"? Had Husserl been captured by "the climate of opinions (Joseph Glanvill)?"

I should note that it is imperative that the reader pay close attention to Calcagno's analysis of Stein's "reworking" Husserl's Ideas II, found in chapter one, pages 14-18. Here, Calcagno explicates Husserl's "transcendental" shift from a position that defined "logical operations of the mind as developed in

\footnotetext{
${ }^{5}$ Ibid., 2.

${ }^{6}$ Ibid., 7-8.

${ }^{7}$ Voegelin, Collected Works of Eric Voegelin, Vol.12, 310.

${ }^{8}$ Ibid., 310-311.
} 


\section{R. CHEEKS 173}

his Logical Investigations to an a priori, necessary, and universal notion of consciousness that would ground, Husserl claimed, all sciences." 9

Stein picked up on the derailment immediately, as did a number of Husserl's colleagues, and pleaded with the philosopher to reconsider, but he steadfastly refused. Husserl had abandoned the phenomenology ground in favor of "the standard neo-Kantian idealism of the university (Freiburg), thereby abandoning what his students saw as his Gottingen phenomenological 'realism.'10

Calcagno arranges the chapters to coincide with Stein's "philosophical development" excluding a critique on her doctoral thesis, On the Problem of Empathy, because it is the "best known by English readers," and was conducted under the direction of her mentor, Edmund Husserl. The author seeks to show that Stein was much more than Husserl's protégé, that she conducted serious philosophical inquiries on her own.

Chapter one is a biographical essay that explores her life and reveals a woman that was "unconventional, challenging, and controversial." She entered the University of Breslau but transferred to the University of Gottingen in 1913 to study under Husserl because she had read his Logical Investigations and wished to pursue phenomenology whose appeal to Stein, Calcagno writes, “. . . lay in its criticism of both relativism and psychologism, the doctrine of explaining events and ideas in purely psychological terms, that is, as affectivity."11

While Husserl's Logical Investigations developed her philosophical direction, another book, Teresa of Avila's Autobiography, provided a profound pneumatic event that opened the door to her own theophanic experience. By 1921 Edith Stein had become a Christian (Roman Catholic) philosopher. Calcago points out that the most significant factors establishing Stein's essence was "the Gottingen circle (a group of philosophers, teachers, and students who gathered to investigate philosophical problems, from a phenomenological perspective), feminism, phenomenology, and her conversion to Catholicism. ${ }^{12}$

Calcagno fully explores Stein's efforts, after she obtained her doctorate (summa cum laude) from the University of Freiburg (1917), in applying for Habilitation (the process of becoming a university professor in Germany), in the "blatant sexism" she confronted which included sarcasm from Husserl and the dismissive comments of Heidegger.

However, part of her requirements for habilitation was to write an original work of philosophy. Stein's disquisition would be titled, Finite and Eternal Being, and while Calcagno describes it as a work ". . . which attempts to bring Husserlian, medieval, and Thomistic thought together," 13 it is, I think, a profound examination of the essence of being, reality, and the metaleptic communion.

\footnotetext{
${ }^{9}$ Calcagno, op cit, 14

${ }^{10}$ Ibid., 16.

${ }^{11}$ Ibid., 8.

12 Ibid., 9.

13 Ibid., 14.
} 


\section{THE PHILOSOPHY OF EDITH STEIN}

Stein does not seek to abandon the old symbols, rather, she successfully recovers the truth inherent in these symbols and moves to recover human existence as it is experienced in the tension between the immanent world reality and the transcendent, (i.e. between this place and God). She reveals herself as a philosopher "attuned" to God's order, not as one engaged in egophanic revolt or one suffering a psychological disturbance (morbis animi). She rejects the derailment of "self-salvation" inherent in Nietzsche and Hegel and correctly places being in a "flow of existence that is not existence in time." 14

Further, Stein eschews the "restricted horizons" exhibited by the various "school," philosophies and methodologies that plagued the early twentieth century. She was in the fore in the revolt against these "restrictive deformations," exhibited by her philosophizing in the classical method of seeking, questing, and searching, her profound dedication to the truth in reality, and her desire to engage in rational discourse. ${ }^{15}$

Finally, Calcagno explicates Stein's concept of the "personality core," which is defined as ". . . the essence of the soul which harbors character and makes a person psychologically and spiritually unique." $16 \mathrm{He}$ also explains that the person is the essential theme of Stein's philosophy, showing that she outlined certain "structures" that are required, phenomenologically, "for us to experience persons and communities." Stein was the first to write of women and sexual differences as they are defined phenomenologically as well as a phenomenological examination of community, and she successfully synthesized the work of Thomas Aquinas and Husserl while revealing "their respective shortcomings."

In chapter two, Stein's Phenomenology of Community, Calcagno introduces the reader to Stein's work, Philosophy of Psychology and the Humanities. Here, the author examines Stein's notions of community, both in terms of subjectivity and intersubjectivity, and the relationship of community and the individual.

Chapter three, Persona Politica, The Person as the Point of Unity and Difference in the State, is derived from Stein's essay, An Investigation of the State. It is an in-depth analysis of Stein's treatment of the relationship between the person and the state. Calcagno argues that "Stein does not wish to offer her readers a utopian concept of the ideal state,"17 then explicates Stein's notion that the state has ontic structure defined by the mass, community, and society; all of which incorporates the concept of the person.

Calcagno argues that Stein "invokes the Aristotelian notion of phila or the Latin amicitia (friendship) as being the bond that unifies the state, more so than justice."18 He interprets Stein's phila as the possibility of "significant dialogue and personal interaction." The question is, is it possible to engage in this dialogue and interaction in the modern state?

\footnotetext{
${ }^{14}$ See Voegelin, Collected Works of Eric Voegelin, Vol. 12, 74-78.

15 See ibid., 308-10.

16 Ibid., 18.

17 Calcagno, op cit., 46.

18 Ibid., 56.
} 


\section{R. CHEEKS 175}

The very structure of the modern state, its bureaucrats, politicians, political parties, lobbyists, and hangers-on define the human predilection for corruption, and considering the on-going decline of moral standards and the societal loss of fides.

While Stein is speaking of the "possibilities" concerning the relationship of person to the state, we must ask, given the "fallen nature" of man, what form of the "state" best suits Stein's desired condition.

The answer might be found within an historical framework. There are certain analogies that can be made in terms of Stein's Weimar, Germany and the contemporary United States. While Stein's Germany was moving inexorably toward empire, today the United States has achieved that condition. The United States began its history as a federalist state and has now declined into a social democracy. ${ }^{19}$ Historically, democracies inevitably evolve into the dictatorship. The American empire has broken away from the political ground of its federalist founders and has entered into a political phase brought about by what Calcagno correctly identifies as "the postmodern condition."

Eric Voegelin clearly discerned the condition when he wrote, "... we can see what is defective about the whole idea of empire. It lacks the factor of the spirit. It is one of the great achievements of the later church to have found the balance between spirit and power, and to have seen that while social organization of a sort is necessary, it is certainly not the end of things, unless it is penetrated by the substance of spiritual order."20

Consequently, Stein's desired relationship between the state and the person may be best achieved within the framework of the republic, because the republic is best suited to, publicly at least, restrain the libido dominandi.

Chapter four, Empathy as a Feminine Structure, Calcagno explores Stein's seminal study of women from a phenomenological perspective. Stein believes "essences are universals," that her general descriptions of universals applied to the feminine are accurate while still retaining room for "the radical personality core," and even the occasional nuance of a male trait or two. And, while male and female "share a common humanity" we are "marked by a duality."

The author reveals a delightfully radical concept, at least in terms of contemporary feminism, in Stein's argument that the "relationship of soul to body differs in their (male and female) psychic life as well as that of the spiritual faculties to each other." 21 Further, she avers that women are "more holistically and psycho-spiritually constituted"; men are more prone to individual tasks; women are more intuitive. All of which is presented with the

${ }^{19}$ On the subject of republican virtues, Msgr. Robert Sokolowski in his essay, "The Human Person and Political Life," in Christian Faith and Human Understanding (Washington, D.C., Catholic University of America Press, 2000) 184-5, writes, "Aristotle says that the best outcome for most people in most places at most times, the practically best form of the city generally, is the republic, the politeia, which is intermediate between the oligarchy and democracy. In a republic, a large middle class-middle in both economic and an ethical sense-is established between the rich and the poor, and the laws and not men rule, and they do so for the benefit of the whole city, not for any particular part."

${ }^{20}$ Voegelin, Collected Works of Eric Voegelin, Vol. 12, 110.

${ }^{21}$ Calcagno, op cit., 70. 


\section{THE PHILOSOPHY OF EDITH STEIN}

caveat that ". . . there are no capacities in men that are not present in women and vice versa." 22

Chapter five, Freedom, Responsibility, and Intentionality: The Question of the Specifically Human is Edith Stein's response to the question of what it means to be human? Calcagno takes Steins response from her work, The Structure of the Human Person, where she defines the specifically human in terms of freedom and the associated responsibility.

After an erudite analysis of Husserlian phenomenology and Steinian interpretations, Calcagno explicates Stein's differentiations: 'In other words, there is a responsibility that ensues from our free acts. We are the bearer or executioner of the free acts and they necessarily bend back upon us or refer to us, thereby imposing on us the need to respond. This "ought" springs from the soul and is not necessarily rooted in consciousness." 23

Calcagno argues that Stein's position is that by deeply considering what it is to be human we can repress our fallen nature described by St. Augustine as the libido dominandi.

In chapter five, The State and the Immortal Soul of the Person, Calcagno explores Stein's phenomenology of the state. He asks if the state has any responsibility for the mortal soul of the person. Here he annunciates three points: he returns to Stein's theme of phila as it pertains to the relationship between the person and the state, which invokes a certain civic theology, an acknowledgement of the state's authority, and the need for the state to allow an "ontological space" where people can critique the state.

Stein then concludes that the state, indeed, does have an "ontic responsibility" for the soul of the person. The author takes up the cause by arguing that the elimination of the death penalty may be justified by the premise that ". . . the immortal soul points to a responsibility for its well-being that is not uniquely our own but also God's," 24 which raises the question, should the state sanction and/or fund abortion?

In the final chapter, Heidegger and Stein on the Question of Being, Calcagno engages in a systematic and in-depth analysis of the phenomenological differences in the work of Heidegger and Stein. He explores Stein's critique of Heidegger's Being and Time, concentrating on Stein's inquiries into the definition of the word, Dasein, the adequacy of that term, and posits the question, is the Heideggerian analysis sufficient to act as a ground for "approaching the question of the sense of being"?

Calcagno explains that Stein's objection with Heidegger's use of the term Dasein (human being, humankind, being-in-the-world) is that he associates the essence of being as existence, a definition formerly ascribed to God, thereby destroying the metaleptic reality.

Stein's critique is also predicated with Heidegger's disengagement with traditional metaphysics. She suggests, Calcagno tells us, "that a more thorough

$$
\begin{aligned}
& { }^{22} \text { Ibid., } 71 . \\
& { }^{23} \text { Ibid., } 91 . \\
& 24 \text { Ibid., } 110 .
\end{aligned}
$$




\section{R. CHEEKS 177}

examination of thinkers like Thomas, Aristotle, and other Greeks may have proven challenging." 25

Calcagno's book is a thorough, erudite, and sometimes poignant exegesis of the thinking of a gifted philosopher. He illustrates Stein's penetrating and insightful observations, her resistance of the disorder inherent in modern thinking brought about by the Enlightenment Project and later philosophers, and her efforts to re-establish the bond between Reason and openness to the ground.

From the pages of Calcagno's book there emerges a philosopher engaged in the classic analysis of Reason differentiated by fides and an intense desire (oregontai) to-if we may use the Christian symbol- "dwell in the spirit of the Lord." From the life of a scholar/philosopher Edith Stein moved into a noetic existence, where she-if we may use the Greek symbol-engaged in "the practice of immortalizing (athanatizein)."

In the end, she was required to sacrifice her life in her quest for the Truth, and, indeed, in the Socratic tradition and for "her people," she did just that.

Robert C. Cheeks is an independent scholar from Lisbon, Obio, United States

\section{References}

Calcagno, Antonio, The Philosophy of Edith Stein (Pittsburg: Duquesne University Press, 2007).

Sokolowski, Robert, "The Human Person and Political Life," in Christian Faith and Human Understanding (Washington, D.C.: Catholic University of America Press, 2000).

Stein, Edith, Finite and Eternal Being, in The Collected Works of Edith Stein, Vol. Nine (Washington, D.C.: ICS Publications, Institute of Carmelite Studies, 2002).

Voegelin, Eric, Collected Works of, Vol. 12 (Missouri: The University of Missouri Press, 1990).

25 Ibid., 125. 